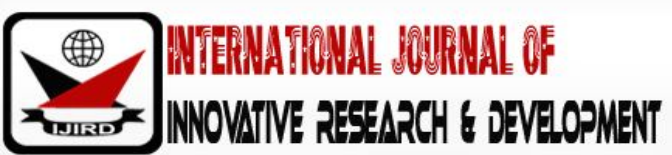

ISSN 2278 - 0211 (Online)

\section{Poverty and National Security in Nigeria}

\author{
Dr. Victor Semawon Akran \\ Senior Lecturer, Department of History and War Studies, Nigerian Defence Academy, Kaduna, Nigeria
}

\begin{abstract}
:
Although poverty is a global phenomenon, its effects on the security of each country vary. In Nigeria with a large population of people living below the poverty level, the poor masses become, restive and vulnerable in their desperation to forge a living. It is in this circumstance that criminally minded leaders (political or religious) manipulate the vulnerable poor masses to carry out their wishes. It is the vulnerability of the poor for easy manipulation that threatens national security. This study becomes imperative due to the protraction of many violent conflicts, insurgencies and terrorist activities in the country. The study was shown that radical, extremist leaders depend greatly on the use of the poor masses in threatening national security in Nigeria.
\end{abstract}

Keywords: Poverty, terrorism, national security

\section{Introduction}

Poverty is a potential threat to the security of a nation. At the communal level, the leadership enjoys the cooperation of the subjects in order to ensure the security of life and property. That mutual cooperation can only be sustained when the leadership also ensures the comfort and well-being of the subjects. In a larger society, this symbiotic relationship is really between the top echelon and lowest class, who are predominantly the poor. The responsibility of ensuring the security of life and properly of the society and by extension that of a nation rests squarely on the defense structure of the nation. But theirservices to the state in terms of security are hinged on how much the state remunerates when the state cannot put in place certain minimum conditions that can alleviate poverty, then poverty becomes a threat to the security of the nation.

Poverty is a global phenomenon. In every nation, a proportion of the populations fall within the poverty level. However, the level of poverty of the individual and the proportion of those within the poverty bracket vary from one nation to another. In the developed Nations, also referred to as the third World Countries, and particularly in Africa, there is a wide gap in the ration of the rich to the poor. With a very large population of poverty-strickenpeople, the level of vulnerability of all forms of voices including criminality becomes very high especially when there no hope of assistance from the government, the economic community and Wealthy individuals that could bale the poor out of poverty.

Poverty in itself is not Synonymous with insecurity; it is the level of the vulnerability of the poor to criminal tendencies that threatens national Security.

This paper attempts a narrative on the level of poverty in the country by identifying the issues and conditions which increased the level and size of poverty. Also, the paper discusses how the poor have been manipulated in order to escalate sustain and prolong riots, militancy and terrorism which threaten the security of the nation. The paper focuses on the activities of leadership and how it mobilized the poor to strengthen the group to carry out terrorist activities.

\subsection{Security}

The concept of security has its application to this paper. Several scholars have given their views on this concept, such scholars included Adam Smith FS Northadge and Arnold Wolfers. ${ }^{3}$ Their views equated security with the use of military strength or the power of the nation to secure and protect its territory and the people. This explanation of the concept of security does not give the meaning that fits into the views of this paper.

Mc Namara on his part stated that "Security is development and without development there can be no security"4. This implies that security is synonymous with development.

Development ensures security. There can only be development when the nation's labour force is gainfully employed and their well-being is guaranteed and taken care of; when children and youth of school age, have access to education of all forms and are encouraged to acquire skills; when essential facilities for comfort are within reach and are affordable and; when the resources of the country are fully taped and fairly evenly distributed.

These are the indices of development and they are dimensions of security such as economic security, social security and a high quality of life of the citizens. ${ }^{5}$ The National Security policy provides the direction and the framework for development of the national economy to ensure growth, employment, food security and improved standard of living. 6 In spite of the National Security policy, increasing population of Nigerians continued progressively to be insecure. It was this decline in 
and ethno-religious conflicts, militancy, oil bunkering, agitations, insurgencies and terrorism, all of which still occur till date.

\subsection{Poverty}

Scholars and groups express different views on the concept of poverty. People have a general understanding of what it means to be poor and to exhibit poverty. But the definitions of poverty vary with each individual. The United Nations Habitat described poverty as a multi-dimensional nature and so monetary measure alone is not enough to determine the true nature of poverty. Indices of poverty include over crowded housing, low quality housing or insecure housing, lack of safety network support, lack of law on economic, social and cultural rights and lack of law on environmental health ${ }^{7}$. Martin Revallion and Benu Bidani define poverty as the lack of capabilities to participate with dignity in social activities or a lack of command over basic consumption needs. It refers to people whose consumption expenditure is below a specific poverty line. That poverty line is the level of family income which is below where a family may be considered poor ${ }^{8}$.

According to Jude Ndu, poverty implies that the standard of living of the poor is considerably lower than the acceptable of norm. The acceptable norm. it is hunger and not knowing where the next meal is coming from; not having a roof over your head and having nowhere togo; being sick and not being able to see a doctor; death of a child from a preventable illness and no money to pay for medications; not being able to go to school; being unemployed and no chance of getting a decent job9. Similarly, Lipton States that there is widespread agreement that a person is in absolute primary poverty if the extent that his resources are too fem to meet basic needs of food and shelter ${ }^{10}$.

From the various views on poverty, the following general conditions are identified as indicators of poverty. They include; inadequate asset, overcrowded residence, low quality or lack of secure housing, lack of safety network, to protect, to regulate economic, social and cultural rights against discrimination and environmental health. Although the World Bank has defined poverty as living on less than $\$ 2$ (two dollars) per day while extreme poverty is living below $\$ 1$ (one dollar) per day, the living condition of the poor is brutal.

\subsection{Poverty in the Developed Nation}

Up to the early years of the $20^{\text {th }}$ century, many of the developed nations had high level poverty. These nations included China, Japan, Germany, England and United State of America11 for instance England had a high level of poverty when in 1834; the poor law Act was passed by the parliament. It was only by 1945 that the poverty level reduced considerably. Similarly, in the United State of America, poverty was still prevalent in 1964. But as seen as President Lyndon Johnson was elected into office in that year, he showed great determination to eradicate poverty by putting measures in place..$^{12}$ It follows that the level of poverty in Europe, part of America and part of Asia was drastically reduced between 1945 and 1970 through deliberate and determined efforts which met affordable, employment, housing, social welfare schemes and developing countries of Africa; poverty has remained to the Secretary General of the United Nation, Mr. Kurt Waldheim, in 1974, "the single most devastating indictment of our current worldcivilization is the continued existence of stark, pervasive mass poverty among two-thirds of the most population". ${ }^{13}$ He posited that poverty permeates every phase of life in developing countries. It manifests as malnutrition in children, outbreak of disease, widespread unemployment, low literacy, overcrowded cities ${ }^{14}$. It is the most basic, most obvious and most rampant of the problems of developing countries. Poverty is the mother problem which has produced all the ills and evils of our socio-economic life. ${ }^{15}$ Robert S. Mc Namara, at the 1975 Annual Meeting of the Board of Governors, estimated the population of the poor in the developing countries when he stated; " there are some 700 million individuals locked into absolute poverty in the rural areas of the developing world". ${ }^{16}$ It is characterized by malnutrition, illiteracy disease, squalid surroundings high infant mortality and how life expectancy. ${ }^{17}$

In the sub Saharan Africa, about 298 million which translate to $30 \%$ of the total population live in extreme poverty as at $2004^{18}$. In 2015 the average percentage of the poor figures give a general picture of the sub region, the specific case of the countries give varying percentages, while the percentage is higher in some countries, it is lower in other countries. Again, looking at the global picture, poverty level is low in the countries in Europe and American, and that explains the high level of their development. But in the third world countries in Asia and Africa, poverty prevalence is very high and so the rate of development remains low. In juxtaposing poverty situation on security, the picture in the countries of Europe and America is that of high level security with low level poverty while the reverse is the case in the third world countries. Therefore, threats to national security remains higher in the third world countries than in the developed countries. Also, in the countries of Europe and America threats to national security are carried out by individuals who open fire in public places like schools, commercial areas and in sporting areas. But in the third world countries, armed group in large numbers embark on all national security.

\subsection{Poverty and Security Threats in Selected Third World Countries}

Afghanistan: Insurgency in this county is a mixture of traditional, persistent conflicts among small groups, led by powerful figures and global insurgent group based on radical Islam such as Haqqani Network, Hezbu Islam and AlQaeda. ${ }^{19}$ Prior to 2001, the Taliban was in power. But due to the Afghanistan war of 2001, the Taliban lost political conflict with the government, the National Security Forces and their NATO trainers. In 2002 the Taliban launched renewed Jihad against the government. The group established small training camps along the border with Pakistan for new recruits who were mainly the poor. Major camps were created in the mountainous areas of Pakistan and they operate in all parts of the country ${ }^{20}$. The insurgents have operated for 23 years in Afghanistan and specifically between 2006 and 2012 over 79 major attacks were carried out on the military, the police and the civilian population. But more specifically, between March 
19, 2009 and March 19, 2011, 2770 Afghan policemen were killed and 4,785 wounded while 1,052 Afghan soldiers were killed and 2,413 wounded. ${ }^{21}$

Iraq: Insurgency in Iraq began in May, 2003 by an armed group with a base at Fallujah and around Baghdad in what is known as Sunni Triangle. By June 2003 over 36,533 civilians were killed from soft targets with the use of sophisticated weapons and improvised explosive devices (IEDs) by suicide bombers. ${ }^{22}$ By February 2006, the insurgency escalated into Civil War till 2008 when the war reduced into insurgency again and by 2011 the insurgency escalated. This was due to existence of several Sunni groups which are linked to the global Jihad phenomenon, established by Abu Mushad Zargawi, known as Al-Qaeda's emir of Iraq.23

Yemen: Insurgency in Yemen is led by the shia, also known as the Houthi rebellion, Sa'dah war or sa'dar conflict. It started in June 2004 when dissident cleric Hussein Badroddin al-Houthi, head of the shia Zaidiyyah sect, launched an uprising against the Yemeni Government. It was in reaction to an attempt to arrest the head, al-Houthi. In 2009, the Yemeni army offensive against shia rebels led to displacement of hundred Yemen.24

Mali: The Tuareg are nomadic-pastoralist group who since 1960s after Mali's independence felt excluded and neglected by the government. They began to oppose government policies especially on land matters, coupled with severe drought between 1968 and 1974 in the Sahel which killed a large number of them and their cattle with little or no assistance from government. While many of them migrated to Algeria and Libya, a group of them at home began insurgency against the government and the non-Tuareg farmers. The armed tuaregs attacked convoys of supplies to Timbuku in Mali and Agades in Niger 25.

In response to the attacks, the non-Tuareg armed farmer groups came together to form a large political organization called the Ganda Koi, meaning land owner in Songhoi (Famer language). Sporadic fighting between the Tuareg insurgents and the Malian government continued in the 1990s. Again, in July 2012 Islamic insurgents in Timbuku arose and engaged in destructive activities. Also, the Al-Quaeda in the Islamic Magred, a regional criminal gang some other insurgent groups and a Tuareg separatist group. The up surge and terrorist activities was due to the collapse of Muammar $\mathrm{Al}$ Qadhafi's regime in lybia ${ }^{26}$.This led to the return of Tuareg combatants and armed groups back to Mali. It also led to rampant movement of arms within the West Africa region. The situation led the displacement of over 42,000 people leading to food scarcity.

A large insurgent group was formed by the merger of another group in Mali and Niger, known as the National Movement for the Liberation of Azewad (MNLA). In 2012, the National Movement for the Liberation of Azewad was joined by Ansar al Deen, another Tuareg Islamist group. They murdered many soldiers and civilians in the Northern town of Aguelhok. The murdered many soldiers and the grievances it generated within the military led to the military coup of March $2012^{27}$.

So, Mali, like Libya has been reduced to chaos with the rule by terrorists and extremists and it is becoming the home for international terror campaigns to destroy modern Africa.

Egypt. Insurgency in Egypt is traceable to Islamist groups who were excluded from government and who engaged the government and the people in conflict and other forms of violence from 1988 to 200. The main Islamist extremists who engaged in violence activities were al-Jama'al-Islamiya and al-Jihad. After 1997 insurgency reduced.

By 2011 insurgent activities escalated as Islamist movements attached Christian Copts, the police and the government of Hosni Mubarak²8.

Apart from the exclusion and marginalization of the Islamist movements, another important cause of insurgency was the rising food prices which forces Egypt to import large quantities of food. A large population of Egyptians lived below poverty line. Also, the living conditions of many Egyptians especially the peasants, workers and middle class, who constituted a large majority of the population deteriorated.

The Arab Spring. The Arab Spring is a name given to the revolutionary wave of demonstrations and protests occurring in the Arab world. It is taking the form of pro-democracy uprising, the awakening, the Arab uprising and the Arab rebellion which is sweeping the Middle East and North Africa ${ }^{29}$.

The Arab Spring is sweeping through the following Africa Countries:

- $\quad$ Tunisia: Starting from December 17, 2010

- Egypt: Starting from January 25, 2011

- Yemen: Starting from January 26, 2011

- Libya: Starting from February 17, 201130

The Arab Spring arose due to a protest by a Tunisian street vendor who set himself ablaze in protest of police abuse. Added to this was wide spread corruption, food inflation, high unemployment and lack of political freedom.

Arab Spring was also an Islamic Spring led by the Muslim Brotherhood and Salafist Islamist parties in Egypt, Libya, Syria and Tunisia. It resulted in the fall of Housni Mabarak's government in Egypt. And this fall affected American interests in the north of Africa ${ }^{31}$.

Apart from the financial loss on the countries involved in the Arab Spring, these countries also suffered loss of lives and the migration of thousands of people from violence in Western and Central Africa ${ }^{32}$.

\section{Tracing the Level of Poverty in Nigeria Since 1960}

Towards the end of colonial rule, Nigeria produced hundreds of thousands of primary school's leavers who left the villages and rural areas to the big towns in search of jobs. And they added also with large population of school leavers in the big towns who were in search of government jobs and jobs in European firms. But due to lack of industries, they were not all fully employed. Also, the first National Development plan of 1962 to 1968, focused attention on increasing the utilities such as health, water, electricity and the educational facilities at the federal and regional levels. Apart from the fact 
that these utilities did not provide tangible job opportunities, such jobs did not raise the standard of living of the people since it did not raise real income. 33

Again the $2^{\text {nd }}$ and the $3^{\text {rd }}$ National Development Plan (1970-1974 \& 1975-1980) did not contribute to the development of the rural areas due to unprecedented efflux of the labour force from the rural area ${ }^{31}$. It follows that ruralurban migration of the labour force in search of jobs in Lagos, Port Harcourt, Ibadan, Enugu, Kaduna and Kano among others, led to increasingly large population of unemployed young school graduates in the urban areas. Similarly, the neglect of agriculture and traditional industries in the rural areas due to countries migration of labour to the urban areas increase the population of the poor and the level of poverty in the rural areas and as Adejugbe summed it, the years from 1960 to 1990 was a period within which most Nigerians wallowed in poverty amidst opulence. This was due to the fact that the quality and quantity of industrialization in the cities provided far less job opportunities than the opportunities required for absorbing the large number of migrants into the Cities ${ }^{35}$. For instance, the population of Lagos due to ruralurban migration and the growth of its urban population, by 1991 was 6.8 million ${ }^{36}$. And by 2017, its population must has risen to more than 10 million.

Most migrants are young adults within the age bracket of 15 to 35 years. They migrate in search of paid jobs or other opportunities to improve themselves materially yet increasing number of the migrants do not have jobs. In addition, there was acute shortage of basic facilities such as portable water, housing, and environmental sanitationlack of these basic facilities was evidence of poverty. Added to these, was unemployment and under employment. For instance, only $31 \%$ of the urban population in 1990 received pipe-borne water which reduced to $24 \%$ in 1999 ; 37\% got water from street vendors and $24 \%$ from water tankers and 39\% relied on boreholes ${ }^{37}$ Thus the quality of water is poor thereby posing danger to the health of urban dwellers particularly the low income and very poor people with high rate of waterborne diseases such as cholera, typhoid fever and dysentery 38 .Similarly,housing is inadequate both in quality and quantity. Many housing units lacked good sanitation and uninterrupted water supply and a great proportion of households live in one-room apartment 39 . The urban environmental problems include liquid and solid waste management and water pollution. Unemployment rate for youths between 15-19 years was $47 \%$ and adults between 20 and 24 years was $28 \%$ by 1983. And immediately after the introduction of structural Adjustment programme.

In the densely populated slums of Lagos, Aba, Onisha, Kaduna, Kano, Maiduguri and Port Harcourt. Militant groups unleash extreme violence on the civil society. Others forced ethnic militant groups to scale up urban violence while others protect the interest of their nationalities. They become vigilante organizations which otherprotect the people against brigands, miscreants, and armed robbers and their criminals 40 . Violence is caused by deprivation, rising frustration, unemployment for the educated or school leavers, youth unemployed or under employed for example membership of OPC were by both educated and uneducated class is the unemployed university graduates and secondary school leavers; artisans e.g. battery chargers, tailors, motor mechanics, vulcanizes, workers and petty traders whose efforts to earn their living had been frustrated by inadequate power supply, insecurity, poor economy 41 .

It is necessary to note the poverty situation in Nigeria as described by Remi Babalola, former Minister of State for the Finance: Poverty in Nigeria is widespread. But despite all the interventions to reduce poverty. The poverty profile is still high. ${ }^{42}$ According to him, the profile showed that in 1980, poverty figure was $28.1 \%$ but increased in 1985 to $46.3 \%$ then declined in 1992 to $42.7 \%$. In 1996, the figure increased to $65.5 \%$. In absolute terms the estimated population of Nigerians living below poverty line in 2007 was more than 80 million while in 2015 more than $60 \%$ of Nigeria live below the poverty line out of an estimated population of 182.2million, gives an estimate of 201.32million ${ }^{42}$. In 2017, about 70\% of Nigeria's population in lived below the poverty level.

Though the bulk of the population of the poor is living in the rural communities but there are also urban poor who are illiterate and unskilled. The table below, given by the Central Bank of Nigeria identifies 20 states with the highest and lowest incidences of poverty.

\begin{tabular}{|c|c|c|c|c|c|}
\hline \multirow[t]{2}{*}{ S/ NO } & $\begin{array}{l}10 \text { State with } \\
\text { incidence of }\end{array}$ & $\begin{array}{l}\text { Highest } \\
\text { Poverty }\end{array}$ & \multirow[t]{2}{*}{ S/NO } & \multirow{2}{*}{$\begin{array}{l}10 \text { State with } \\
\text { incidence of } \\
\text { State }\end{array}$} & $\begin{array}{l}\text { Lowest } \\
\text { Poverty }\end{array}$ \\
\hline & State & \%Position & & & \%Position \\
\hline 1 & JEGAWA & 95.0 & 1 & BAYELSA & $20.0 \%$ \\
\hline 2 & KEBBI & 89.7 & 2 & ANAMBRA & 20.1 \\
\hline 3 & KOGI & 88.6 & 3 & ABIA & 22.3 \\
\hline 4 & BAUCHI & 86.3 & 4 & OYO & 24.1 \\
\hline 5 & KWARA & 85.2 & 5 & IMO & 27.4 \\
\hline 6 & YOBE & 83.3 & 6 & RIVERS & 29.1 \\
\hline 7 & ZAMFARA & 80.9 & 7 & ENUGU & 31.1 \\
\hline 8 & GOMBE & 77.0 & 8 & OGUN & 31.7 \\
\hline 9 & SOKOTO & 76.8 & 9 & 0SUN & 32.4 \\
\hline 10 & ADAMAWA & 71.7 & 10 & EDO & 33.1 \\
\hline
\end{tabular}

Table 1

Source: CBN

The above table reinforces the report released by the United Nation Development Programme, UNDP in April 2017 on Human Development rating of member countries of the United Nation. The report indicated that out of its 188member countries of the world, Nigeria ranked 152. This placed Nigeria as one of the countries with the lowest Human 
Development index in the world. The Human development index is based on the number of people withaccess to education and other basic amenities that lift the people out of poverty line.

\section{Poverty in Nigeria and Threats to Natonal Security}

Insurgencies have occurred in Nigeria at different times and in different forms since the countries got its independence. For instance, Isaac Adaka Boro led an insurgency in the Niger Delta in March 1966 against the country. Similarly, from 1980 to 1982, Muhammed Marwa's followers led his Maitatsine insurgent group against the Nigerians State. There was also militancy in the Niger Delta and the Boko Haram insurgency in the Northeast of Nigeria. Out of the entire example cited the insurgent group led by Isaac the smallest group. This was because Isaac Boro had no time to recruit and mobilize his people for support. In addition, the group was poorly armed, and the leader of the group had no experience in the act of insurgency. So, the group was over whelmed by the action of first Battalion, in Enugu. ${ }^{3}$

This part of the paper discusses the activities of two different groups which activities threatened national security and the role of the poor in the activities of each group. These groups are: the Maitatsine religious group; the Boko Haram terrorists.

The Maitatsine religious sect was formed by MuhammedMarwa, a violent Islamic preacher. He migrated from the Cameroon in 1960s or earlier and he settled in Kano. He was an Islamic extremist, a fanatical preacher who indulged in provocative and defamatory sermons by publicly criticizing and condemning the authorities. ${ }^{43} \mathrm{He}$ was also a notorious criminal. He had an intimidating record of breaking the law.For instance, he smuggled himself in to Nigeria in a breach of immigration law. On several occasions he was deported. Also, he was in prison in 1962 in Kano, in Makurdi and again in 1977 and between 1979 and 1980 he had sixteen cases of illegal and violent preaching. He had a deep-rooted hatred for the authorities; particularly the police. ${ }^{44}$ going by attributes of Marwa and as a religious leader, in an environment that was largely religious and poverty-stricken masses, Marwa was strategically poised to win over the masses to his vanguard. He established his enclave a Yan'awaki, the slum area of Kano City. From there his followers increased in leaps and bounds and in hundreds of thousands, in Jimeta, Adamawa, Marwa was a terror to his neighbors in yan'awaki. ${ }^{45} \mathrm{He}$ had large followers in Gombe, Bauchi; and in Kaduna.

Violent riot brook out following the fourteen-day ultimatum given to Marwa and his group by Government Abubakar Rimi on 26 November 1980, to vacate his enclave. So intense was violence that none of its type occurred before 1980 anywhere in Nigeria since the end of the civil war. ${ }^{46}$ The size of his followers can be determined by the number of casualties during the violent riots.

The Aniagolu Commission of inquiry estimated that the rioters were between 6,000 and 10,000 followers. Out of this estimate, about 4,177 were killed. The report added that:" Nobody could say with any degree of accuracy the number of fanatics who died during the disturbances". 47 but according to police report a total of 5,493 were killed.48 although there was no figure of people injured, certainly more people were injured than those who died. Therefore, the actual figure of the Maitatsine rioters or followers of Muhammadu Marwa in Kano was far more than 10,000. This figure comprised largely of "almajirai" students, school dropouts, unemployedyouth's miscreants, artisans and other low-income earners. Theviolence in Kano went on steadily for more than 6days. This was largely due to the number of rioters involved, the extent to which they were armed, and their desperation and determination bearing in mind that they had nothing to lose. After a respite of two years, a series of Maitatsine violent riotsbroke out in their part of the north including Bullum Kuttu in Maiduguri, in October 1982, in Rigasa. Kaduna in October 1982, Jimeta, yola in 1984 and in Pantami, Gombe in 1985. The reoccurrence of the 1980 Kano riot in the identified places was due to the easy movement of the fleeing members of the group from Kano. The movement of the poor was very easy, and hardly drew the attention of the authorities. They moved over long distances in trucks, lorries and the railway. It was in these ways that the hundreds of Maitatsine group fled Kano. For instance in Jimeta, the fanatics settled in three areas namely, Nassarawa, Doubeli and these areas had cheap houses for low income earners and good hide out for Vilikilang. They occupied houses in large criminals for Gardama thereby overcrowding the area and terrorizing their neighbors such that they started fleeing the area, thereby drawing the attention of the security operative to the threat to national security 49 . Within a short time, the fanatics had mobilised sufficiently with arms. Their enclaves were in the remote slums with no access roads. Like the riot in Kano, that of Doubeli also lasted for five days. That was also because it involved a large number of the poor.The figure of the rioters is made clearer when one knows the number of the victims. A total of 893 people were reported killed, as indicated on theregister by the Yola Metropolitan and Urban Development Board as well as by the Yola Teaching Hospital. This figure does not include those who were buried by members and other individuals but were but were not taken to any hospital. The estimate of the people who were injured was not also included. It follows therefore that the Maitatsine rioters in the three locations in Jimeta Yola numbered between 1,500 and 2000. This estimate could be the same in Gombe and in Kaduna where similar riots took place. Although the last of the Maitatsine riot took place in Pantami in Gombe in 1985, the crushing of the riot did not mark the end of Maitatsine in northern Nigeria. This view is based on the obvious fact that the remnants of the Maitatsine group survived the crushing of their riots. And as it is with the masses who were underprivileged and who wallowedin abject poverty, they remained committed to the cause of the leader even years after his demise. They held on to his doctrines, his ideology and the goal of Maitatsine. Among those who carried on the memories of Muhammed Marwa was Muhammed Yusuf, a young man from poor family background. Mallam Yusuf was the founder of an Islamic sect known as Jamat Allis Sunna Ladda awwati wal jihad. This means the people committed to propagation of prophets' teachings of Jihad 50 . But the public referred to the sect as Boko Haram, from Hausa language which in English means 'Western education is sacrilege or a sin'. Boko in Hausa language refers to western education while Haram in Arabic refers to; Sacrilege or sin'. 
Anifowose traced the origin of this sect to Maitatsine when Muhammed Yusuf was ${ }^{51}$ probably an almajirai in 1980. This position is reinforced by the similarity in the meaning of Maitat-sine and Boko Haram. Also like Muhammed Marwa, Muhammed Yusuf was a violent and virulent preacher. These three factors aided Boko Haram to take the place of Maitatsine, from 2001. First, Muhammed Yusuf came from poor background and so he easily built the sect around the poor masses. Second, he was a young student of Muhammed T Marwa. This enabled him to win the support and the loyalty of the remnants of the defunct Maitatsine fanatics in their thousands. Third, Muhammed Yusuf had the gift of persuasion through preaching just like Muhammed Marwa. Though preaching he won more converts. In this may, his followership increased tremendously.

Up to 2002, the Jamat Ahlis Sunna LIdda awwati Waljihad sect operated peacefully 52 in Bauchi Yobe State and Maiduguri in Borno sate. While it operated peacefully, it also began to arm its followers perhaps in preparation for its Jihad. By 2009 when the group had its first violent confrontation with the security agencies in Bauchi the sect had branches in Bauchi Yobe, Brono and Kano. The first clash in July 2009 resulted in the death of over 700 members of the sect.53 another source show that over 1000 people died .54 After about two years of respite, another more violent encounter with the police and military occurred, in November 2011, in Damaturu, Yobe state when over 150 members were killed. Again on 22 and 23 December 2011 there was simultaneous violence in Damaturu which resulted in the death of over 100 fanatics. ${ }^{5}$

Consequently the violent confrontation which the Boko Haram fanatics had with the security agencies on the $26^{\text {th }}$ and 27th July 2009, trigged off acts of terrorism in Nigeria which is still ongoing, and which is being perpetrated by the poverty-stricken members of the group.

The Maitatsine sect and Jama'at ahl as-sunnah li-d-da'awati ma-l-jihad exploited poverty in the land to perpetuate terrorism in the northern part of the country. Both sects established their bases or cells in the slum areas of the north and in the midst of the poor, thereby they gained popularity among the poor populace. In fact, the leaders of Jama'at ahl assunnah were among the almajirai (itinerant students) of Muhammadu Marwa, leader of the Maitatsine extremist sect. this implies that they were members of the Maitatsine even though they were quite young in the 1980s when the Maitatsine riots took place in parts of the north. This view was reinforced by Hajiya Aisha Wali, who is known as Mama Boko Haram. She claimed to have known Muhammed Yusuf and his friends since they were much younger. According to her, these young boys came frequently and were free with her. They would come to her house and stay to eat and occasionally ask for money. This attitude showed the level of their poverty. Also the origin philosophy, ideology and meaning of Jama'at ahl assunnah li-d-da'awati wa-l-jihad are traceable to those of Maitatsine. The Hausa word "tatsine" refers to something that is cursed or condemned. So, as an extremist religious sect, it condemned that state and the apparatus sect of governance as 'cursed' in so far as they did not conform to the fundamentals of Islam as advocated by Marwa in his preaching's. In the same way, Jama'at ahl as-sunnah condemned westernization of Nigeria: the government, its apparatus and education. Their condemnation of anything western was derived from the apparent failure of the newly elected state governments in the north, to fully implement the sharia law to letter. The emphasis on sharia from 2002 when most state governments in the north failed to fully implement it contrary to the campaign promises before 1999. The promise by the campaign promises among fanatical Muslims and especially among the poor populace.

Perhaps the biggest attraction to the sect by the poor masses was the welfare scheme which Muhammed Yusuf established from 2001. The scheme was so enticing and tempting. It gained widespread awareness and it mobilized the poor widely. The wealthy members were appealed to, for them to finance the sect. they donated large sums of money and land. Muhammed Yusuf also had close interaction with the politicians and highly placed government officials. It was disclosed that he had some agreements with Alhaji Ali Modu Sherrif. But what was the deal with the Borno state government, it was clear that Mohammed Yusuf had some relation with government, more so that one of his followers/ sponsors was a commissioner in the government of Ali Modu Sheriff. Similarly it was claimed that the state government paid some amount of money to the group when Mohammed Yusuf died. They money paid to the group boosted its campaign among the poor. The campaign was backed by financial gifts to those who joined the group.

More financial support came from sponsors. Mohammed Yusuf approached some prominent wealthy traders, business men and politicians such as Alhaji Bunu Wakil, Alhaji Salisu Damaturu, Muhammed Goni, Mohammed Zakaria, Saidu Pindar, Ali Ndume and Alhaji Ali Modu Sheriff. It was funds which came from these and many other sponsors that Yusuf and other Boko Haram leaders used to propagate the sect among the poor masses and to solicit for membership, with financial inducement. It was claimed that a large number of poverty stricken accepted the membership of the sect just because of the new converts was that the funds would continue to be shared for them to continue to improve their well-being. With the generous and free distribution of cash to the poor, the unemployed, school dropout, daily paid worker, street hawkers and miscreants, they became committed to terrorism.

Even children soldiers were enticed by money to carry out suicide bombings on identified targets. As poor children, it was the money that force them to detonate IEDs even when they were aware that they would be blown up.

Another major enticement was the philosophy of Jama'at Ahlis Sunna Lidda awwati wal jihad which guaranteed every soldier of the sect easy way to paradise after death and in paradise, they would live in mansions with enormous wealth and be married to seven virgins. This kind of guarantee reposed a good level of assurance and confidence to carry out deadly activities like suicide bombing and the plundering of defenceless communities, burning houses and engaging in mass killing of people in so many parts of northeastern states of Nigeria.

\section{Conclusion}

The real threat to National Security can be appreciated through a careful examination of the circumstance that led to terrorism in Nigeria since 1980. This paper has attempted to show that the level of poverty in Nigeria and particularly 
in the northeast continued to rise due to neglect. However, Mohammed Marwa, a preacher from Cameroon who had subversive and reasonable tendencies, shielded his intents under the guise of religion to manipulate the un suspecting large population of the unemployed youths, the school dropouts, the uneducated and the almajerai who in their hopelessness, consoled themselves by the demonstrating absolute loyalty to their spiritual leader who the firmly believed would take them to salvation. Due to the demonstration of a good understanding of the Islamic knowledge through his style of preaching. His followers increased in thousands. Even when the action of Marwa began infringing on the laws of the land, and the law enforcement agents arrested and detained him, his large followers did not see the need to desert him. Marwa was therefore encouraged to take greater steps towards his eventual confrontation with the state. In this may be stock piled arms and thereby turned religiousfaithful into armed group.

It was through a similar process that Muhammed Yusuf transformed his sect into an armed group between 2002 and 2009, thereby served as threats to national security.

Before the violent confrontations with the security force, both poor followers in both groups were again manipulated by the political goals. Muhammed Marwa was drawn closer by the Kano state Governor while Muhammed Yusuf had Cordial relationship with Borno state Governor. Both political leaders at different times. Exploited the existence of the two-armed groups; Maitatsine and Boko Haram, to impose their will and wishes on their two states. Certainly it was through such relationship with the political class that both insurgent groups got funds and other forms of support which were diverted to promote their terrorist activities, because the helpless poor remained committed to the cause of their leaders. And so, even though Maitatsine group was crushed in 1985 and Boko Haram group is being degraded, the high rate of poverty in the north and particularly the northeast will continue to spirit and doctrine of criminality insurgency and terrorism alive.

\section{References}

i. D Whyness, the Economics of the third World Military Expenditure, in Victor A Elaigmu, the Military and the Management opf Civil Crises in Nigeria, 1960- 1993, Kaduna, Nigeria Defence Academy Press 2003 p47

ii. FS Northedge, the Foerign Ploices of the power London, Faber and Faber, 1963 p17

iii. Victor A Elaigmu th Military and the

iv. RS McNamara, the Essence of Security, New York, Harper and Rom, 1968 p 149; Victor A Elaigmu, th Military and the ... p48

v. Ozocmennam Mbachu, the Management of National Security in Nigeria, Ozoemenam Mbachu, Ahmed Aliyu Sokoto (eds) Nigeria Defence and Security: Polices and stretegies, Kaduna: Medusa Academic Publishers Ltd, 2011p 168

vi. Ibib; $\mathrm{p} 16 \mathrm{p}$

vii. Ime Ekop ebong, General introduction to issues of poverty and its Alleriation, ime Ekop Ebong, the War on poverty in Nigeria: Isuues, problemsm strategies, Lagos IEA Publishing 2001 p16

viii. Ibis; p17

ix. Jude Ndu, Business Day, April 30, 2008 p 22

x. Michael Lipton, poverty under nutrition and Hunger WBSWP,

xi. Ime Ekop Ebong General introduction to issues of poverty and its Alleviation...p2

xii. Ibid;

xiii. 13.Ibid;p3

xiv. 14.Ibid;p4

xv. 15.Ibid;p5

xvi. 16.Ibid

xvii. 17.Ibid

xviii. 18.Ade Abolurin Insurgency, Ibadan; Golden-Gems

xix. 19. Unique Multiventures, 2015 p52

xx. 20.Ibid; p54

xxi. 21.Ibid

xxii. 22.Ibid; 774

xxiii. 23.Ibid;p86

xxiv. 24.Ibid; p91

xxv. 25.Ibid; p114

xxvi. 26.Ibid; pp 115-116

xxvii. 27.Ibid;

xxviii. 28.Ibid; p130

xxix. 29. The Arab Awakening. 2011, the Economist, July 14. In Wikiprogress.org. Arab spring on 13 September 2012 A.Korotater and J. Zinikina, Egyptian Revelation: A Demographic structural Analysis, in Wikiprogress.org.

xxx. Arab Spring on 13 September 2012.

xxxi. 30. Chief Abul of what is the Arab third Estate, Huttingon post in wikiprogress.org. Arab Spring on 13 september 2012

xxxii. 31. Ade Abolurin, IInsurgency ... p140

xxxiii. 32. Ibid; $\mathrm{p} 141$

xxxiv. 33. MOA Adejugbe, Industrialization, Urbanization ans Development in Nigeria 1950-1999, Lagos, Concept Publication Ltd, 2004 p 21

xxxv. 34. Ibid. 
xxxvi. 35.Ibid; p22

xxxvii. 36. Chinue N,anna Rural-Urban Migration and population problems in Nigeria Cities, MOA Adejugbe (ed) Industrialization, Urbanization ...p p4

xxxviii. 37. Ibid; $\mathrm{p} 62$

xxxix. 38.Ibid.

xl. 39.Ibid; $\mathrm{p} 63$

xli. 40. Remi Anifomose, Urban Violence in Nigeria: The case of the oodua people's Congress (OPC), Militia, MOAAdejugbe (ed) Industrialization, Urbanization ... pp231-33

xlii. 41. Ibid; $\mathrm{p} 247$

xliii. 42. Remi Babalola, A Road map to sustainable Micro finance in sub-saharan Africa, Micro finance confrerence, Lagos, August 2008

xliv. 43. Victor A Elaigmu the Military and the Management of civil crises in Nigeria 1960-1993, Kaduna: Nigerian Defense Academy press, 2003 p 144

xlv. 44.Ibid. pp 143-144

xlvi. 45.Ibid; p 145

xlvii. 46.Ibid.

xlviii. 47. Report of the Kano State Disturbances Tribunal of Inquiry.

xlix. 48.Ibid.

1. 49. Victor Elaiggwmu the Military and the Management ...p 150

li. 50. Ade Abolurin Insurgency ... p 156

lii. 51. Anifomose Tajudeen, " Understanding Boko Haram, Islam and Development," Nigerian Tribune, 22 June 2012 $\mathrm{p} 40$

liii. 52. Ade Abolurin Insurgency ... p 174

liv. 53.Ibid.

lv. 54. Mike Boni Bazza, Boko Haram Terrorist: My personal story as a Victim, Lagos: Atrick Venture Limited, $2014 \mathrm{p}$ 27

lvi. 55. Ibid;p 29 